\title{
PENGERTIAN LINKED OBJECT
}

\author{
Anugrah Ananda Nauli Siregar \\ 185100014 \\ Fakultas Komputer \\ anugrahananda.student@umitra.ac.id
}

\begin{abstract}
Dalam suatu linear list kita dapat melakukan operasi penyisipan atau penghapusan atas elemen-elemennya pada sembarang posisi.

Misalkan ada 1500 item yang merupakan elemen dari suatu linear list.

Jika elemen ke-56 akan kita keluarkan, maka elemen ke-1 s/d elemen ke-55 tidak akan berubah posisinya pada linear list tersebut. Tetapi elemen ke-57 akan menjadi elemen ke-56, elemen ke-58 akan menjadi elemen ke-57 dst. Selanjutnya, jika kita sisipkan satu elemen pada posisi setelah elemen ke-41, maka elemen ke-42 s/d elemen ke-1500 akan berubah posisinya.

Untuk menyatakan keadaan diatas diperlukan suatu konsep yang berbeda dengan konsep sekuensial sebelumnya.

Linked list merupakan suatu cara non-sekuensial yang digunakan untuk merepresentasikan suatu data.
\end{abstract}

Kata Kunci : Linked list merupakan suatu cara non-sekuensial yang digunakan untuk merepresentasikan suatu data 


\section{A. PENDAHULUAN}

Pesatnya teknologi, terutama teknologi komputer sudah tak bisa dipungkiri lagi, bagi yang mengikuti perkembangannya, ia tidak akan dipandang sebelah mata. Sebaliknya, bagi yang tidak mengikuti perkembangannya, bersiaplah untuk mundur secara suka rela dari panggung kompetisi. Ibarat wabah, teknologi komputer sudah menyusupi hampir semua bidang kehidupan manusia. Dari pemerintah pusat sampai tingkat pemerintah desa, perusahaan-perusahaan, supermarket, minimarket, perguruan tinggi,SLTA, SLTP, bahkan SD hampir semuanya mengenal komputer. Saat ini, yang mempunyai lingkungan yang semakin luas dan banyak diminati, juga dapat digunakan untuk menghasilkan uang adalah dunia pemrograman komputer. Dalam dunia pemrograman komputer, dikenal banyak bahasa pemrograman, seperti C, C++, Pascal, Basic, Java, dan lain-lain.

Jika di kembangkan dari berbagai bahasa pemrograman ini terdiri dari beberapa struktur data, dan diantaranya adalah linked list. Dalam pemakaian sehari-hari istilah senarai berantai (linked list) adalah kumpulan linear sejumlah data. Banyak contoh yang menunjukkan senarai berantai seperti pada daftar belanjaan, yang berupa barang pertama, kedua, ketiga dan seterusnya. Untuk hari berikutnya, maka daftar tersebut bisa berubah sesuai dengan barang yang harus dibeli lagi atau barang yang tidak perlu dibeli lagi. Kemudian hari kedua belanja lagi tiga buah barang dan menghapus dua barang yang telah tidak terpakai dari daftar barang yang telah dibeli hari kemarin, hal ini dapat diartikan sebagai senarai berantai.

Pengolahan data yang kita lakukan menggunakan komputer seringkali mirip dengan ilustrasi di atas, yang antara lain berupa penyimpanan data dan pengolahan lain dari sekelompok data yang telah terorganisir dalam sebuah urutan tertentu. Salah satu cara untuk menyimpan sekumpulan data yang kita miliki adalah menggunakan larik. Keuntungan dan kerugian pemakaian larik untuk menyimpan sekelompok data yang banyaknya selalu berubah dan tidak diketahui dengan pasti kapan penambahan atau penghapusan akan berakhir

\section{B. PEMBAHASAN / STUDI KASUS}

A. Linked List (Senarai berantai)

Senarai berantai(bahasa

Inggris:linked list) atau

kadang-kadang disebut dengan

senarai bertaut atau daftar bertaut dalam ilmu computer merupakan sebuah struktur data yang digunakan untuk 
menyimpan sejumlah objek data biasanya secara terurut sehingga memungkinkan penambahan, pengurangan, dan pencarian atas elemen data yang tersimpan dalam senarai dilakukan secara lebih efektif. Pada praktiknya sebuah struktur data memiliki elemen yang digunakan untuk saling menyimpan rujukan antara satu dengan lainnya sehingga membentuk sebuah senarai abstrak, tiap-tiap elemen yang terdapat pada senarai abstrak ini seringkali disebut sebagai node. karena mekanisme rujukan yang saling terkait inilah disebut sebagai senarai berantai. Sebuah senarai berantai dengan tiap-tiap node yang terdiri atas dua elemen, data integer, dan elemen rujukan ke node berikutnya. Senarai berantai merupakan bentuk struktur data paling umum dan sederhana yang banyak digunakan untuk mengimplementasikan model struktur data lainnya, termasuk antrian, stack, ataupun larik assosiatif.

Senarai berantai (linked list) terdiri dari dua bagian yaitu senarai berantai satu arah atau biasa disebut single linked list , dan senarai berantai dua arah atau double linked list. Namun pada kesempatan kali ini, akan lebih banyak membahas tentang double linked list. Seperti halnya dengan program-program yang lain yang memiliki kekurangan dan kelebihan, program linked list pun memiliki kekurangan dan kelebihan. Keuntungan utama pemanfaatan senarai berantai dibandingkan larik, ataupun senarai biasa adalah kemudahan dan efektifitas kerja yang lebih baik dalam hal menambah, mengurangi, serta mencari suatu elemen/node yang terdapat dalam senarai. Hal tersebut dimungkinkan karena elemen-elemen yang terdapat pada sebuah senarai berantai tidak ditempatkan pada sebuah blok memori komputer seperti halnya larik ataupun senarai biasa, melainkan tiap-tiap elemen/node tersebut tersimpan dalam blok memori terpisah, penambahan, pengurangan, ataupun penggantian node dapat dilakukan dengan mengubah elemen rujukan atas tiap-tiap node yang terkait. Kerugiannya, sebuah senarai berantai tidak memungkinkan pengaksesan elemen secara acak, dalam artian untuk dapat mengakses node ke tiga, harus dilakukan dengan cara mengunjungi elemen-elemen sebelumnya, dimulai dari elemen pertama, ke dua, seterusnya hingga pada lokasi elemen yang dimaksudkan. Selain itu Kerugian dari senarai yaitu hanya bisa dibaca dalam satu arah saja. Jika ingin membacanya dari arah sebaliknya, tidak bisa melakukannya dengan cara menelusuri pointer, tetapi harus dengan cara rekursif atau 
terlebih dahulu mengubah arah pointernya.

B. Perbedaan single linked list dan double linked list Seperti yang kita ketahui bahwa senarai itu memiliki dua jenis yaitu senarai berantai satu arah (senarai tunggal) atau singel linked list dan senarai berantai dua arah atau double linked list.

Senarai satu arah yaitu bila struktur data sebuah node hanya memiliki satu tautan atas node berikutnya dalam sebuah senarai, maka senarai tersebut dinamakan sebagai senarai tunggal. Senarai tunggal dengan tiap-tiap node yang terdiri atas dua elemen, data integer, dan elemen rujukan ke node berikutnya.

Pada dasarnya, penggunaan Double Linked List hampir sama dengan penggunaan Single Linked List yang telah kita pelajari pada materi sebelumnya. Hanya saja Double Linked List menerapkan sebuah pointer baru, yaitu prev, yang digunakan untuk menggeser mundur selain tetap mempertahankan pointer next. Keberadaan 2 pointer penunjuk (next dan prev) menjadikan Double Linked List menjadi lebih fleksibel dibandingkan Single Linked List, namun dengan mengorbankan adanya memori tambahan dengan adanya pointer tambahan tersebut.
Berbeda halnya dengan senarai tunggal, pada senarai dua arah (singel linked list), struktur data atas tiap-tiap node memiliki rujukan pada node sebelum dan berikutnya.

Sebagian algoritma membutuhkan taut ganda, contohnya sorting dan reverse traversing. Senarai ganda dengan tiap-tiap node yang terdiri atas tiga elemen, data integer, dan dua elemen rujukan ke node sebelum serta berikutnya.

c. ID SECURITY QWTD4452377-ASP-5244107

\section{KESIMPULAN}

Kesimpulan yang dapat ditarik dari pembahasan, yaitu: 1. linked list merupakan sebuah struktur data yang digunakan untuk menyimpan sejumlah objek data biasanya secara terurut sehingga memungkinkan penambahan, pengurangan, dan pencarian atas elemen data yang tersimpan dalam senarai dilakukan secara lebih efektif.

2. Linked list memiliki dua jenis yaitu senarai berantai satu arah (senarai tunggal) atau singel linked list dan senarai berantai dua arah atau double linked list.

\section{E. DISKUSI}

Dari perbedaan single linked list dan doble list di atas, apakah kamu mengerti dengan isi artikel saya? 
Agung Kurniman Putra : Ya, saya mengerti. Single linked list adalah senarai yang satu arah. Sedangkan doble linked list adalah senarai yang ada dari dua arah.

\section{F. REFERENCE}

[1] O. M. Febriani and A. S. Putra, "Sistem Informasi Monitoring Inventori Barang Pada Balai Riset Standardisasi Industri Bandar Lampung," J. Inform., vol. 13, no. 1, pp. 90-98, 2014.

[2] A. S. Putra, "Paperplain: Execution Fundamental Create Application With Borland Delphi 7.0 University Of Mitra Indonesia,” 2018.

[3] A. S. Putra, "2018 Artikel Struktur Data, Audit Dan Jaringan Komputer," 2018.

[4] A. S. Putra, "ALIAS MANAGER USED IN DATABASE DESKTOP STUDI CASE DB DEMOS."

[5] A. S. Putra, "COMPREHENSIVE SET OF PROFESSIONAL FOR DISTRIBUTE COMPUTING."

[6] A. S. Putra, "DATA ORIENTED RECOGNITION IN BORLAND DELPHI 7.0.”

[7] A. S. Putra, "EMBARCADERO DELPHI XE 2 IN GPUPOWERED FIREMONKEY APPLICATION.”

[8] A. S. Putra, "HAK ATAS KEKAYAAN INTELEKTUAL DALAM DUNIA TEKNOLOGY BERBASIS REVOLUSI INDUSTRI 4.0.”

[9] A. S. Putra, "IMPLEMENTASI PERATURAN
PERUNDANGAN UU. NO 31

TAHUN 2000 TENTANG

DESAIN INDUSTRI

BERBASIS INFORMATION TECHNOLOGY.”

[10] A. S. Putra, "IMPLEMENTATION OF PARADOX DBASE."

[11] A. S. Putra, "IMPLEMENTATION OF TRADE SECRET CASE STUDY SAMSUNG MOBILE PHONE."

[12] A. S. Putra, "IMPLEMENTATION

PATENT FOR APPLICATION WEB BASED CASE STUDI WWW. PUBLIKLAMPUNG. COM."

[13] A. S. Putra, "IMPLEMENTATION SYSTEM FIRST TO INVENT IN DIGITALLY INDUSTRY.”

[14] A. S. Putra, "MANUAL REPORT \& INTEGRATED DEVELOPMENT ENVIRONMENT BORLAND DELPHI 7.0.”

[15] A. S. Putra, "PATENT AS RELEVAN SUPPORT RESEARCH.”

[16] A. S. Putra, "PATENT FOR RESEARCH STUDY CASE OF APPLE. Inc.”

[17] A. S. Putra, "PATENT PROTECTION FOR APPLICATION INVENT."

[18] A. S. Putra, "QUICK REPORT IN PROPERTY PROGRAMMING.”

[19] A. S. Putra, "REVIEW CIRCUIT LAYOUT COMPONENT

REQUIREMENT ON ASUS NOTEBOOK." 
[20] A. S. Putra, "REVIEW TRADEMARK PATENT FOR INDUSTRIAL TECHNOLOGY BASED 4.0."

[21] A. S. Putra, "TOOLBAR COMPONENT PALLETTE IN OBJECT ORIENTED PROGRAMMING."

[22] A. S. Putra, "WORKING DIRECTORY SET FOR PARADOX 7.”

[23] A. S. Putra, “ZQUERY CONNECTION IMPLEMENTED

PROGRAMMING STUDI CASE PT. BANK BCA Tbk.”

[24] A. S. Putra, D. R. Aryanti, and I. Hartati, "Metode SAW (Simple Additive Weighting) sebagai Sistem Pendukung Keputusan Guru Berprestasi (Studi Kasus: SMK Global Surya)," in Prosiding Seminar Nasional Darmajaya, 2018, vol. 1, no. 1, pp. 85-97.

[25] A. S. Putra and O. M. Febriani, "Knowledge Management Online Application in PDAM Lampung Province," in Prosiding International conference on Information Technology and Business (ICITB), 2018, pp. 181-187.

[26] A. S. Putra, O. M. Febriani, and B. Bachry, "Implementasi Genetic Fuzzy System Untuk Mengidentifikasi Hasil Curian Kendaraan Bermotor Di Polda Lampung," SIMADA (Jurnal Sist. Inf. dan Manaj. Basis Data), vol. 1, no. 1, pp. 21-30, 2018.

[27] A. S. Putra, H. Sukri, and K. Zuhri, "Sistem Monitoring
Realtime Jaringan Irigasi Desa (JIDES) Dengan Konsep Jaringan Sensor Nirkabel," IJEIS (Indonesian J. Electron. Instrum. Syst., vol. 8, no. 2, pp. 221-232.

[28] D. P. Sari, O. M. Febriani, and A. S. Putra, "Perancangan Sistem Informasi SDM Berprestasi pada SD Global Surya," in Prosiding Seminar Nasional Darmajaya, 2018, vol. 1, no. 1, pp. 289-294. 